\title{
Gastrintestinal helminths Of Cerdocyon thous (Linnaeus, 1766 - Smith, 1839) from the caatinga area of the Paraíba State, Brazil
}

\author{
Helmintos gastrintestinais de Cerdocyon thous (Linnaeus, 1766) \\ Smith, 1839 provenientes da área de caatinga do Estado da Paraíba, \\ Brasil
}

\author{
Roberto César Lima ${ }^{*}$; Estevam Guilherme Lux Hoppe²; José Henrique Tebaldi³; \\ Breno Cayeiro Cruz ${ }^{4}$; Albério Antonio Barros Gomes²; Adjair Antonio Nascimento ${ }^{5}$
}

\begin{abstract}
The crab eating fox, Cerdocyon thous (Linnaeus, 1766 - Smith, 1839), is a medium sized canid which is found in almost every region of Brazil. It is the only registered native canid specie to be found in the semi-arid Northeastern region of the country. This study had as its objectives: the identification of the helminth fauna common to Cerdocyon thous found in the Caatinga of the state of Paraíba; and the determination of the ecological indications of helminthic infection, hoping to make a favourable addition to the understanding of this little known biome. In this study, 58 animals that were found as 'roadkill' on the highways in the municipality of Patos were used. The gastrointestinal helminths from these animals were colected. All the animals in this study were infected with helminths. 16 species of helminths were identified, two being trematodes, one being a cestode, one being an acanthocephalus, and the remaining twelve being nematodes. In this study a new specie, named Pterygodermatites pluripectinata $\mathrm{n}$. sp. was discovered and its host and location described.
\end{abstract}

Key words: Caatinga, Cerdocyon thous, helminth fauna, ecological descriptors

\section{Resumo}

\begin{abstract}
O cachorro-do-mato Cerdocyon thous (Linnaeus, 1766), canídeo de porte médio, com distribuição em quase todo território brasileiro, com ocorrência no semi-árido Nordestino. No presente estudo objetivou identificar a helmintofauna nesta especies animal, provenientes da região da Caatinga, estado da Paraíba. Para maior abrangência da pesquisa, foi determinado, também, os indicadores ecológicos de infecção helmíntica, contribuição favorável para o conhecimento da biodiversidade do bioma. Para tal, foram utilizados 58 animais encontrados por atropelamento em rodovias nas proximidades do município de Patos, dos quais foram retirados o trato gastintestinal, e posteriormente, realizada a colheita de helmintos; todas os animais necropsiados estavam parasitados. Foram identificados diferentes classes, sendo dois Trematóda, um Cestóda, um Acantocéfala e 12 Nematoda, totalizando 16 espécimens. Neste estudo, uma nova espécie denominada Pterygodermatites pluripectinata $n$. $s p$. foi descrita, além da descrição de novos registros de hospedeiros e localizações.

Palavras-chave: Caatinga, Cerdocyon thous, helmintofauna, indicadores ecológicos
\end{abstract}

\footnotetext{
${ }^{1}$ Graduate student, doctor's degree at Universidade Estadual Paulista “Júlio de Mesquita Filho", UNESP, Jaboticabal, SP, Brazil. E-mail: betolimavet@yahoo.com.br

${ }^{2}$ Profs. at UNESP, Jaboticabal, SP, Brazil. E-mail: e.hoppe@gmail.com; alberiogomes@bol.com.br

${ }^{3}$ Employee at UNESP, Jaboticabal, SP, Brazil. E-mail: tebaldi@fcav.unesp.br

${ }^{4}$ Graduate student, master's degree at UNESP, Jaboticabal, SP, Brazil. E-mail: breno.c.cruz@hotmail.com

${ }^{5}$ Prof. at UNESP, Jaboticabal, SP, Brazil. E-mail: adjair@fcav.unesp.br

* Author for correspondence
} 


\section{Introduction}

Caatinga is an uniquely brazilian biome, that reaches all states in the Northeastern region, as well as the Minas Gerais state, in the Southeastern region of Brazil, with a total area of 734.478 $\mathrm{Km}^{2}$. Despite being an homogeneous biome, its biodiversity is scarce, although recent studies show a superior existence of ecotypes and species than that observed in other biomes. It has unique climatic and pedological conditions, counting with a considerable number of endemic species (SILVA et al., 2003).

The mammalian class is the one with the smaller number of species notifications registered in this biome, probably due to the dificculty in occupying niches. Amogst the canids, only Cerdocyon thous (Linnaeus, 1766 - Smith, 1839) has its occurrence registered in Caatinga, though other species in this family are occasionaly in ecotone areas of surrounding biomes. This is probably due to the generalized aspect of $C$. thous, even being capable of benefiting from the anthropic actions, exploiting food waste from household animal creations (SILVA et al., 2003).

In wild animais, parasitic infections cause damage to the host's healthiness, being less frequent when compared to domestic animals In natural conditions, the parasite/host balance is in such a way that the parasitic load is usually compatible with the survival of the animal. Considering that scientific reports about helminthic infections in C. thous are rare in national literature, and mostly focused on describing new species, this research focused on identifying the helminth fauna of Cerdocyon thous derived from the Caatinga area in the Paraíba state and determining the ecological descriptors of its infection. With these results, the contribution to the knowledge of the region's invertebrate biodiversity in expanded.

\section{Materials and Methods}

Animals and local of the experiment

$58 \mathrm{crab}$ eating foxes (C. thous) were used, found in highways from the northeastern semiarid region, near the Patos municipality, in the Paraíba state, $320 \mathrm{Km}$ away from the coastline, geographically located at $06^{\circ} 46^{\prime} 19^{\prime \prime} \mathrm{S}$ to $07^{\circ} 38^{\prime} 32^{\prime \prime} \mathrm{S}$, and $36^{\circ} 42^{\prime} 52^{\prime \prime} \mathrm{W}$ to $38^{\circ} 08^{\prime} 56^{\prime \prime} \mathrm{W}$, respectivelly at the following highways: BR-230, BR-361, BR-110 and PB-238 (Figure 1). The canids were in a good state of conservation. These were later conducted to the Veterinary Parasitology Laboratory, located in the Center of Health and Rural Tecnology of the Universidade Federal de Campina Grande (UFCG), in the municipality of Patos. Necropsies of the animals were conducted in order to remove the gastrointestinal tract. For the quantification, generic and specific identification of the helminths, all the material was sent to the Parasitic Diseases Laboratory, located in the Preventive Veterinary Medicine and Animal Reproduction Department of the Universidade Estadual Paulista "Júlio de Mesquita Filho" - UNESP, Jaboticabal campus SP. 
Figure 1. Map of Brazil. Enlargement of the Caatinga biome. Image is courtesy of the author: Hoppe et al. 2009, modified.
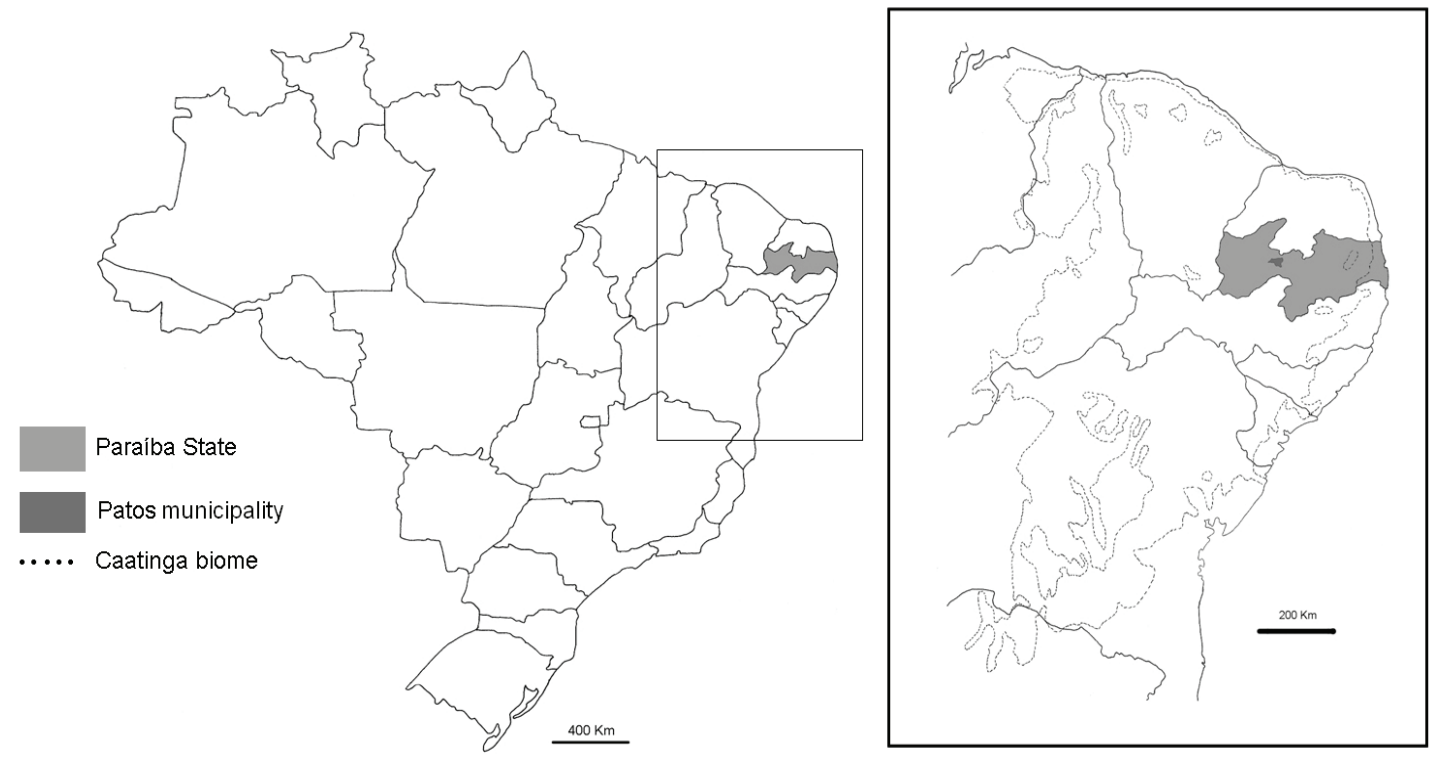

Source: Hoppe et al. (2009).

\section{Colection of the samples}

At the necropsy, the stomach, small intestine and large intestine were separated using double ligatures between their anatomical segments. The contents were removed and the mucosae were scraped. The collected material was washed in strainers (0,297 $\mathrm{mm}$ and Tyler 48) and the solid portion was fixed and preserved in an acetic formaldehyde solution (UENO; GONÇALVES, 1998). After this procedure, the helminths were removed from the gastrointestinal contents with the aid of a stereomicroscope, placed in glass flasks and preserved in acetic formaldehyde solution for their identification. Other organs, such as spleen, liver and pancreas were directeed to other researchers for anatomical studies.

\section{Identification of the helminthic fauna}

The counting and generic identification of the parasites of each segment of the digestive tract was performed. The nematode specimens were clarified with $80 \%$ acetic acid and Beechwood creosote, placed between lamina and coverslip for the visualization and measurement of the morphological caracteristics. The cestodes and trematodes were stained with carmine chloride after compression. For the achievement of the morfometric data, 10 specimens of each gender of helminths were separated, placed between lamina and coverslip amd measured. In case of helminths with less than 10 specimens collected, the measuremente was made in totum. With the aid of a Carl-Zeiss ${ }^{\circledR}$ binocular microscope equiped with camera lucida and the use of a curvimeter, ilustrations and measures were, respectivelly, obtained. All of the identified specimens were separated by sex, counted and, later, bottled and labeled. Vouchers and paratypes were sent to the Helminthology Museum of Fundação Oswaldo Cruz (FIOCRUZ), Rio de Janeiro, to enter the Helminthological Colection (CHIOC), under the trusteeship of Doctor Marcelo Knoff, for cataloguing.

In order to study the sinlofe, when needed, the parasites were previously treated with a clarifying solution and severed with a scalpel blade at the end of the esophagus at the middle portion. The resulting 
material was analised in binocular microscopes, in temporary preparations, following the methods propsed by Durette-Desset (1969).

The parasites were identified according to Ortlepp (1922), Travassos (1937), Machado-Filho (1950), Yamaguti (1961), Travassos, Freitas and Kohn (1969), Quentin (1969), Durette-Desset (1970; 1983), Anderson, Chabaud and Wilmott (1983), Bray, Jones and Andersen (1994) and
Vicente et al. (1997).

Analysis of the results

After finishing the identification and counting of the helminths, a descriptive analysis of the infection indicators stablished by Bush et al. (1997) was performed and the data was related in details, as described below:

\title{
Prevalence $=\underline{\text { Number of hosts infected by the involved specie }}$ \\ Number of hosts examined
}

\begin{abstract}
Abundance $=\underline{\text { Number of involved specimens }}$
Number of hosts examined

Medium intensity $=\underline{\text { Number of specimens from the involved specie }}$

Number of hosts infected by such specie

Intensity variation $=$ minimum and maximum number of specimens from the involved specie observed in the infected hosts
\end{abstract}

\section{Results and Discussion}

All of the necropsied crab eating froxes were infected with helminths distributed in all three segments of the gastrointestinal tract, mainly in the small intestine. 16 specimens of helminths were identified: two trematodes, one cestode, one acanthocephalus and 12 nematodes (Figure 2, 3 and 4 ), with a total of 2.050 identifications (Tables 1 and 2). A small parasitic diversity was shown, with a minimum of one and a maximum of six different species. In all 58 animals the intensity of infection was relatively low, ranging from three to 112 specimens per animal. 
Figure 2. Total number of trematodes, cestodes and acanthocephalus in 58 crab eating foxes (C. thous), derived from the semi-arid region of the Paraíba state, Brazil.

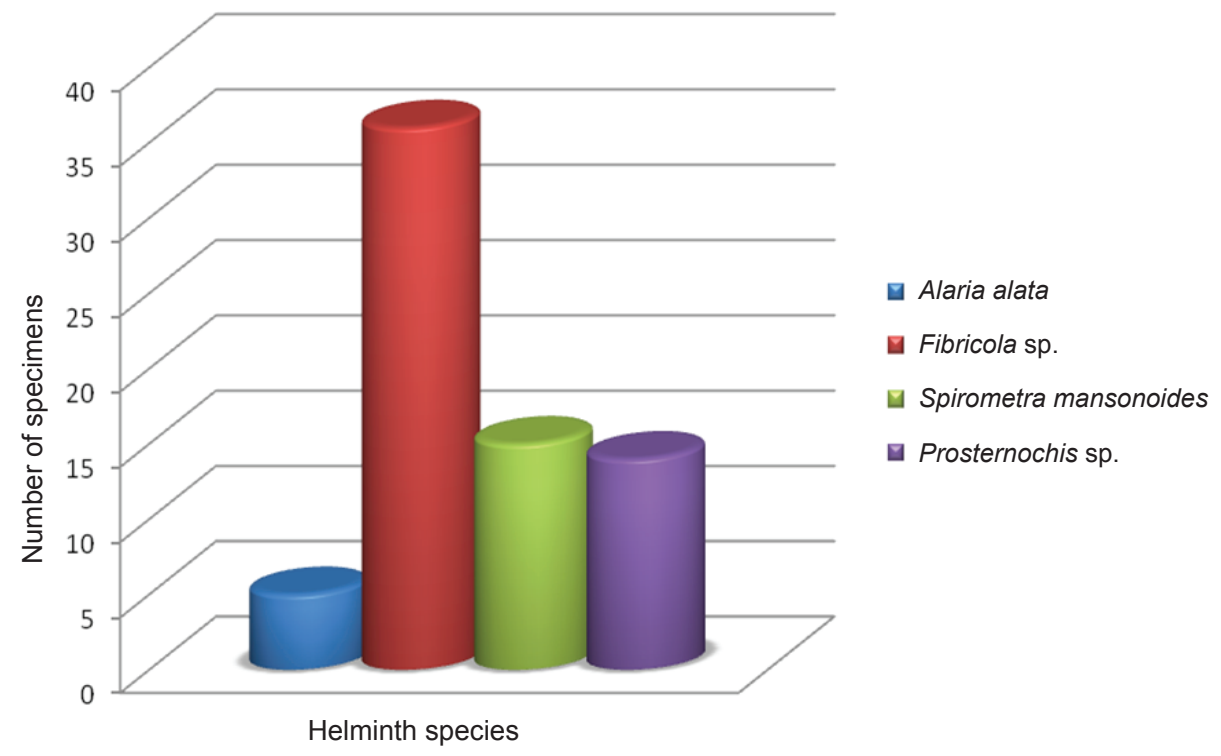

Source: Elaboration of the authors.

Figure 3. Total number of nematodes in $58 \mathrm{crab}$ eating foxes (Cerdocyon thous), derived from the semi-arid region of the Paraíba state, Brazil.

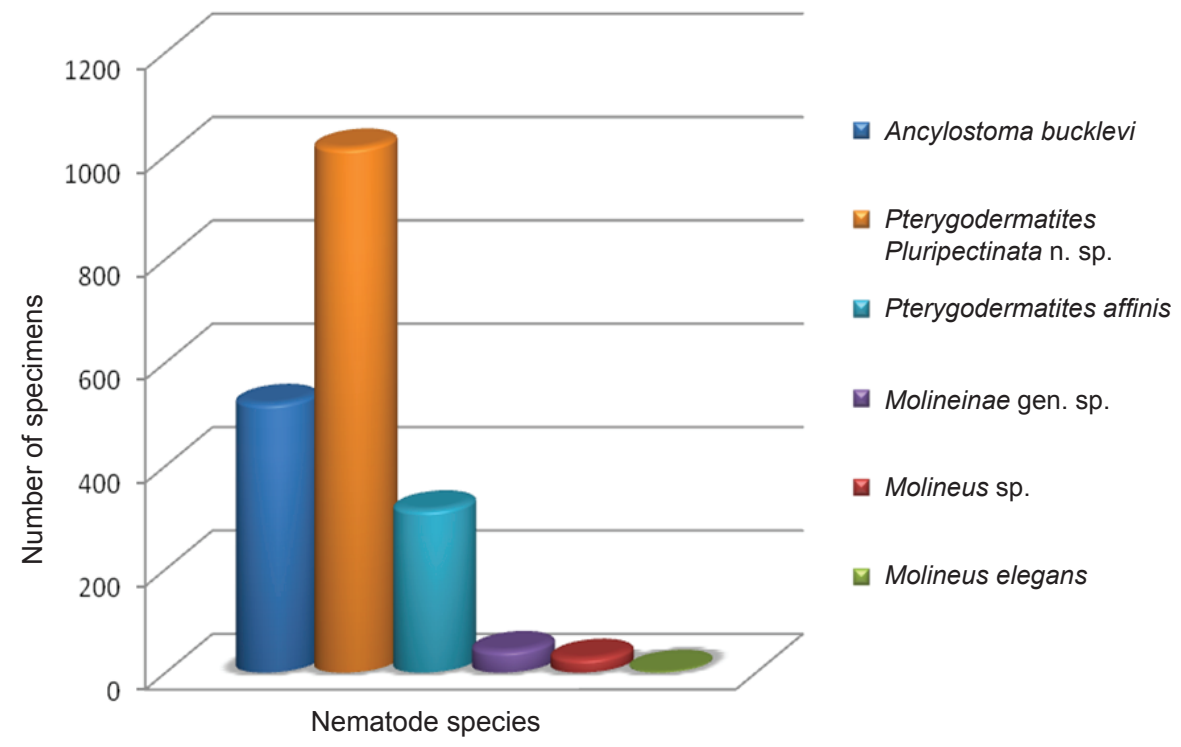

Source: Elaboration of the authors. 
Figure 4. Total number of nematodes in 58 crab eating foxes (Cerdocyon thous), derived from the semi-arid region of the Paraíba state, Brazil.

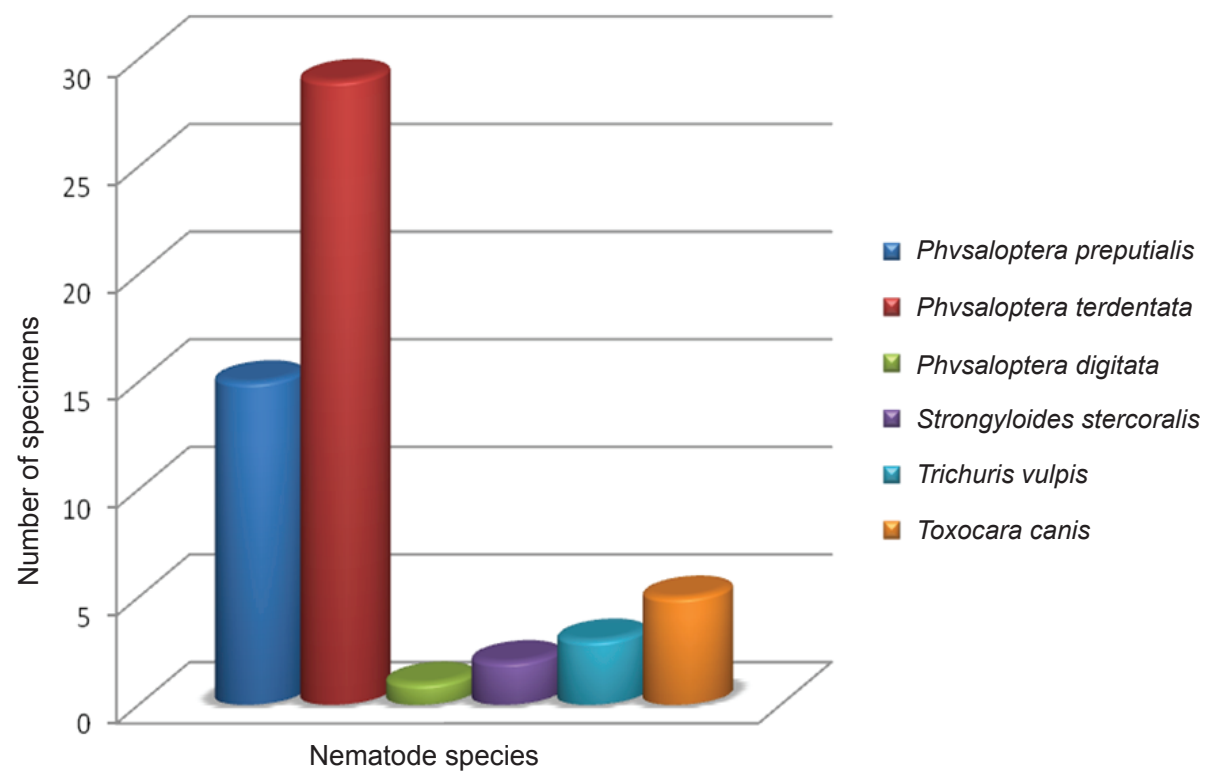

Source: Elaboration of the authors.

Table 1. Total number of trematode and cestode species in 58 crab eating foxes (Cerdocyon thous), derived from the semi-arid region of the Paraíba state, Brazil.

\begin{tabular}{|c|c|c|c|c|c|}
\hline \multirow{2}{*}{ Systematic position } & \multirow[t]{2}{*}{ Habitat } & \multirow[t]{2}{*}{ Specimens } & \multirow[t]{2}{*}{ Total } & \multicolumn{2}{|c|}{ Medium intensity } \\
\hline & & & & Minimum & Maximum \\
\hline \multicolumn{6}{|l|}{ Trematoda } \\
\hline \multicolumn{6}{|l|}{ Diplostomidae } \\
\hline \multicolumn{6}{|l|}{ Alarinae } \\
\hline Alaria alata & SI & 5 & 5 & 1 & 2 \\
\hline Diplotominae & & & & & \\
\hline Fibricola sp. & SI & 36 & 36 & 0 & 36 \\
\hline
\end{tabular}

\section{Cestoda}

Pseudophyllidea

Diphyllobothriidae

\begin{tabular}{lccccc} 
Spirometra mansonoides & SI & 15 & 15 & 1 & 4 \\
\hline Total & \multicolumn{5}{c}{56} \\
\hline
\end{tabular}

Source: Elaboration of the authors. 
Table 2. Total number of nematodes and acanthocephalus in 58 crab eating foxes (C. thous), derived from the semiarid region of the Paraíba state, Brazil.

\begin{tabular}{|c|c|c|c|c|c|c|c|}
\hline \multirow[t]{2}{*}{ Systematic position } & \multirow{2}{*}{ Habitat } & \multirow[t]{2}{*}{ Male } & \multirow[t]{2}{*}{ Female } & \multirow[t]{2}{*}{ Imature } & \multirow[t]{2}{*}{ Total } & \multicolumn{2}{|c|}{ Medium intensity } \\
\hline & & & & & & Minimum & Minimum \\
\hline \multicolumn{8}{|l|}{ Acanthocephala } \\
\hline \multicolumn{8}{|l|}{ Oligacanthorhynchidae } \\
\hline Prosthenorchis sp. & SI & 4 & 10 & 0 & 14 & 1 & 10 \\
\hline \multicolumn{8}{|l|}{ Nematoda } \\
\hline \multicolumn{8}{|l|}{ Rhabditoidea } \\
\hline \multicolumn{8}{|l|}{ Strongyloididae } \\
\hline Strongyloides stercoralis & SI & 0 & 2 & 0 & 2 & 0 & 2 \\
\hline \multicolumn{8}{|l|}{ Trichinelloidea } \\
\hline \multicolumn{8}{|l|}{ Trichuridae } \\
\hline Trichuris vulpis & LI & 1 & 2 & 0 & 3 & 0 & 3 \\
\hline \multicolumn{8}{|l|}{ Ancylostomatoidea } \\
\hline \multicolumn{8}{|l|}{ Ancylostomatidae } \\
\hline Ancylostoma buckleyi & SI & 165 & 356 & 0 & 521 & 1 & 87 \\
\hline \multicolumn{8}{|l|}{ Trichostrongyloidea } \\
\hline \multicolumn{8}{|l|}{ Molineidae } \\
\hline Molinaeinae gen. sp. & STO & 14 & 29 & 0 & 43 & 1 & 8 \\
\hline Molineus sp. & SI & 7 & 21 & 0 & 28 & 3 & 25 \\
\hline Molineus elegans & SI & 3 & 0 & 0 & 3 & 0 & 3 \\
\hline \multicolumn{8}{|l|}{ Ascaridoidea } \\
\hline \multicolumn{8}{|l|}{ Ascarididae } \\
\hline Toxocara canis & SI & 0 & 3 & 2 & 5 & 1 & 3 \\
\hline \multicolumn{8}{|l|}{ Physalopteroidea } \\
\hline \multicolumn{8}{|l|}{ Physalopteridae } \\
\hline Physaloptera praeputialis & STO & 4 & 11 & 0 & 15 & 1 & 6 \\
\hline Physaloptera terdentata & STO & 13 & 16 & 0 & 29 & 1 & 14 \\
\hline Physaloptera digitata & STO & 1 & 0 & 0 & 1 & 0 & 1 \\
\hline \multicolumn{8}{|l|}{ Ricturariidae } \\
\hline Pterygodermatites pluripectinata $\mathrm{n}$. sp. & SI & 435 & 575 & 5 & 1015 & 2 & 88 \\
\hline Pterygodermatites affinis & SI & 105 & 126 & 84 & 315 & 1 & 55 \\
\hline Total & & 752 & 1151 & 91 & 1994 & & \\
\hline
\end{tabular}

Recalling that: STO: Stomach; SI: Small Intestine; LI: Large Intestine.

Source: Elaboration of the authors.

Regarding the generic composition of the infections, 16 helminth species were identified, diverging from results found by other authors (VICENTE et al., 1997; HORTA-DUARTE et al., 2004; RODRIGUES et al., 2006; GRIESE 2007; RUAS et al., 2008), mainly according to the number of nematode species.

The helminths that showed the highest prevalence were: Pterygodermatites pluripectinata n. sp. (93,1\%); Ancylostoma buckleyi (84,48\%); Pterygodermatites affinis (43,1\%); Molineinae gen. sp. (25,86\%);
Spirometra mansonoides (15,51\%); Physaloptera terdentata (12,06\%); Physaloptera preputialis (10,34\%); Alaria alata (6,89\%); Prosthenorchis sp. (6,89\%); Toxocara canis (5,17\%); Molineus sp. (3,44\%). Molineus elegans, Physaloptera digitata, Strongyloides stercoralis, Trichuris vulpis and Fibricola sp. presented a prevalence of $1,72 \%$ each.

The average intensities of infection were the following: Fibricola sp. (36); Pterygodermatites pluripectinata n. sp. (18,79); Molineus sp. (14); Pterygodermatites affinis 
(12,6); Ancylostoma buckleyi (10,63); Physaloptera terdentata (4,14), Prosternorchis sp. (3,5); Molineus elegans (3); Trichuris vulpis (3); Molineinae gen. sp. $(2,86)$; Physaloptera preputialis $(2,5)$; Strongyloides stecoralis (2); Spirometra mansonoides and Toxocara canis $(1,66) ;$ Alaria alata $(1,25)$ and Physaloptera digitata (one specimen by host). The prevalence, intensity and parasitic abundance indexes are described in Table 3.

Table 3. Infection indicators (prevalence, average intensity and abundance) in 58 crab eating foxes (C. thous), derived from the semi-arid region of the Paraíba state, Brazil.

\begin{tabular}{lccc}
\hline \multicolumn{1}{c}{ Helminth species } & Prevalence (\%) & Average intensity & Abundance \\
Trematoda & & & \\
$\quad$ Alaria alata & 6,89 & 1,25 & 0,08 \\
$\quad$ Fibricola sp. & 1,72 & 36 & 0,62 \\
\hline Cestoda & 15,51 & 1,66 & 0,22 \\
$\quad$ Spirometra mansonoides & & & \\
\hline Acanthocephala & 6,89 & 3,5 & 0,24 \\
$\quad$ Prosthenorchis sp. & & & \\
\hline Nematoda & 1,72 & 2 & 0,03 \\
Strongyloides stercoralis & 1,72 & 3 & 0,05 \\
Trichuris vulpis & 84,48 & 10,63 & 8,98 \\
Ancylostoma buckleyi & 25,86 & 2,86 & 0,74 \\
Molinaeinae gen. sp. & 3,44 & 14 & 0,48 \\
Molineus sp. & 1,72 & 3 & 0,05 \\
Molineus elegans & 5,17 & 1,66 & 0,08 \\
Toxocara canis & 10,34 & 2,5 & 0,25 \\
Physaloptera praeputialis & 12,06 & 4,14 & 0,5 \\
Physaloptera terdentata & 1,72 & 1 & 0,01 \\
Physaloptera digitata & 93,1 & 18,79 & 17,5 \\
Pterygodermatites pluripectinata n. sp. & 43,1 & 12,6 & 5,53 \\
Pterygodermatites affinis & & & \\
\hline
\end{tabular}

Source: Elaboration of the authors.

The abundance of helminths were: Pterygodermatites affinis (1-55), Molineus sp. Pterygodermatites pluripectinata n. sp. (17,5); (3-25), Physaloptera terdentata (1-14) and the Ancylostoma buckleyi (8,98); Pterygodermatites affinis $(5,53)$ and the remaining species of identified helminths presented na abundance ranging from 0,01 to 0,74 specimens per examined host, as shown in Table 3. Regarding platyhelminths, a low intensity was observedand only Fibricola sp. Showed expressive variation, due to the fact that only one host was infected.

Amongst nematodes, the species that showed significant intensity (minimum and maximum, respectivelly) were Ancylostoma buckleyi (1-87), Pterygodermatites pluripectinata n. sp. (2-88), acanthocephalus Prosthenorchis sp. (1-10). The remaining species showed

The distribution of the parasitic diversity in the crab eating foxes ranged from one to six helminth species per animal, with the following percentage: one specie $(3,45 \%)$, two species $(29,32 \%)$, three species $(27,58 \%)$, four species $(27,58 \%)$, five species $(10,35 \%)$ and six species $(1,72 \%)$. The parasites that presented higher infection indicators were Pterygodermatites pluripectinata $n$. $s p$. and Pterygodermatites affinis, due to the fact that these parasites possesses a big diversity of intermediate 
hosts, such as insects from the Gryllidae family (crickets) and also the fact that crab eating foxes usually feed on these insects.

Regarding Ancylostoma buckleyi, its expressive prevalence is assigned to its ability to infect the hosts through a percutaneous way, and the fact that its larvae are resistant in environments with a humid micro-climate. In the semi-arid region the access to water is restricted, so the animals usually group near few water reservoirs, such as small lakes and ponds, favoring the maintenance of the parasite's cycle. Trichuris vulpis and Toxocara canis, show a direct life cycle, linked to the feeding habits of the crab eating foxes, which also eat fruits and small animals, making it difficult for these helminths to complete their cycle, as shown by their low prevalence rates. The insignificant prevalence of Strongyloides stercoralis could be due to the age of the animals, mostly adults, since this parasite is more commom in young ones.

The prevalences found in this study differ from the observations made by Gortazar et al. (1998) and Richards, Harris and Lewis (1995) for Pterygodermatites affinis, Trichuris vulpis and Toxocara canis in other canids, as well as for Ancylostoma buckleyi and Alaria alata in C. thous in Brazil (GRIESE, 2007; RUAS et al., 2008). Alaria alata, Spirometra mansonoides, Toxocara canis and Strongyloides stercoralis are responsible for catarrhal duodenitis, human brain sparganosis, visceral larva migrans and enteritis, respectivelly. Since crab eating foxes are hosts of these parasites, and in times when water and food are scarce tend to visit peri-domiciliary areas, they possess a significant zoonotic potential. These foxes can also serve as reservoirs for other parasites, such as Pterygodermatites affinis, Pterygodermatites pluripectinata n. sp. and Ancylostoma buckleyi, all showing high prevalence, acting as a source of infection for domestic dogs and wild canids in the Paraíba state semi-arid region and possibly in other regions of the country. The hookworms ar generally associated with zoonosis, mainly Ancylostoma caninum and $A$. braziliense, suggesting the possibility that Ancylostoma buckleyi might also cause diseases in humans.

\section{Conclusion}

All Cerdocyon thous collected were parasitized and 16 helminth species were identified in the 58 necropsied animals. Amongst these species, the highest prevalences were related to Ancylostoma buckleyi, Pterygodermatites affinis and Pterygodermatites pluripectinata n. sp. From the identified helminths, 13 species represented the first notification on this particular host. Pterygodermatites pluripectina was considered a new specie (n. sp.). in the Caatinga biome, an incredibly rich helminthic fauna, previously unknown, in C. thous was identified in the semi-arid region of the Paraíba state.

\section{Acknowledgements}

To all the employees, researchers and professors of the Veterinary Preventive Medicine Department and to FAPESP, for the financial support and the credibility of the potential of this project.

\section{References}

ANDERSON, R. C.; CHABAUD, A. G.; WILMOTT, S. General introduction; glossary of terms and keys to subclasses, orders and superfamilies. In: .CIH keys to the Nematode of vertebrates. Farnham Royal, Bucks, England: Commonwealth Agricultural Bureaux, 1983. p. 399-403.

BRAY, R. A.; JONES, A.; ANDERSEN, K. I. Order Pseudophyllidea Carus. In: KHALIL, L. F.; JONES, A.; BRAY, R. A. (Ed.). Keys to the cestode parasites of vertebrates. Wallingford, UK: CAB International, 1994. p. 205-247.

BUSH, A. O.; LAFFERTY, K. D.; LOTZ, J. M.; SHOSTAK, A. W. Parasitology meets ecology on its own terms: Margolis et al. revisited. Journal of Parasitology, Lawrence, v. 83, p. 575-583, 1997.

DURETTE-DESSET, M. C. Les systèmes d'arêtes 
cuticulaires chez les Nématodes Héligmosomes parasites de Muridés australiens. Annales de Parasitologie Humaine et Comparée, Paris, v. 44, n. 6, p. 733-747, 1969.

Nématodes Trichostrongyloidea parasites d'edentés sud-américains. Bulletin de la Societé Zoologique de France, Paris, v. 95, n. 1, p. 105-129, 1970.

Keys to the genera of the superfamily trichostrongyloidea In: ANDERSON, R. C.; CHABAUD, A. G.; WILMOTT, S. (Ed.). Cih keys to the nematode parasites of vertebrates. Farnham Royal: Commonwealth Agricultural Bureaux, 1983. p. 81-128.

GORTAZAR, C.; VILLAFUENTE, R.; LUCIENTES, J.; FERNANDEZ DE LUCO, D. Habitat related differences in helminth parasites of red foxes in the Ebro valley. Veterinary Parasitology, Amsterdam, v. 80, p. 75-81, 1998.

GRIESE, J. Helmintofauna de vertebrados atropelados em rodovias da região de Botucatu, São Paulo. 2007. Dissertação (Mestrado em Biologia Geral e Aplicada) Universidade Estadual Paulista. Instituto de Biociências de Botucatu, Botucatu.

HOPPE, E. G. L.; ARAÚJO de LIMA, R. C.; TEBALDI, J. H.; ATHAYDE, A. C. R.; NASCIMENTO, A. A. Helminthological records of six-banded armadillos Euphractus sexcinctus (Linnaeus, 1758) from Brazilian semi-arid region, Patos county, Paraíba State, including new morphological data on Trichohelix tuberculata (Parona \& Stossich, 1901) Ortlepp, 1922 and proposal of Hadrostrongylus ransomi nov. comb. Brazilian Journal of Biology, São Carlos, v. 69, n. 2, p. 424-424, 2009.

HORTA-DUARTE, F.; LOUZADA, G. L.; VIEIRA, F. M.; VALENTE, A. M.; PIFANO, D.; BESSA, E. C. A.; SOUZA-LIMA, S. Ocorrência de helmintos em Cerdocyon thous Linnaeus, 1766 (Carnivora: Canidae) na Zona da Mata Mineira. In: CONGRESSO BRASILEIRO DE ZOOLOGIA, 25., 2004, Brasília. Anais... Brasília: [s.n.], 2004. p. 462.

MACHADO-FILHO, D. A. Revisão do gênero Prosthenorchis travassos, 1915 (Acanthocephala). Memórias do Instituto Oswaldo Cruz, Rio de Janeiro, v. 48 , p. $51,1950$.

ORTLEPP, M. A. The Nematode genus Physaloptera Rudolphi, 1819. Proceedings of the Zoological Society of London, Oxford, v. 2, p. 999-1107, 1922.
QUENTIN, J. C. Essai de classification des nématodes Rictulaires. Mémoires du Musée National d'Histoire Naturell Série A Zoologie, Paris, v. 54, n. 2, p. 55-115, 1969.

RICHARDS, D. T.; HARRIS, S.; LEWIS, J. W. Epidemiological vs studies on intestinal helminth parasites of rural and urban foxes (Vulpes vulpes) in the United Kingdom. Veterinary Parasitology, Amsterdam, v. 59, n. 1, p. 39-51, 1995.

RODRIGUES S. S.; BORGO, P. F.; TAVARES, L. E. R.; SOUZA, T. D. Análise quantitativa e qualitativa de helmintos gastrintestinais de Cerdocyon thous Linnaeus, 1766 (Carnivora: Canidae) encontrados atropelados na rodovia ES 060, Vila Velha - Guarapari, Espírito Santo, Brasil. In: CONGRESSO BRASILEIRO DE PARASITOLOGIA VETERINÁRIA; ENCONTRO LATINO-AMERICANO DE RICKETISIOSES, 2., 2006. Ribeirão Preto. Anais... Ribeirão Preto: CBPV, 2006, p. 297.

RUAS, J. L.; MULLER, G.; FARIAS, N. A. R.; GALLINA, T.; LUCAS, A. S.; PAPPEN, F. G.; SINKOC, A. L.; BRUM, J. G. W. Helmintos do cachorro do campo, Pseudalopex gymnocercus (Fischer, 1814) e do cachorro do mato, Cerdocyon thous (Linnaeus, 1766) no sul do Rio grande do Sul, Brasil. Revista Brasileira Parasitologia Veterinária, São Paulo, v. 17, n. 2, p. 87-92, 2008.

SILVA, J. M. C.; TABARELLI, M.; FONSECA, M. T.; LINS, L. V. Biodiversidade da Caatinga: áreas e ações prioritárias para conservação. Brasília, DF: Ministério do Meio Ambiente, 2003. 382 p.

TRAVASSOS, L. P.; FREITAS, J. F. T.; KOHN, A. Trematódeos do Brasil. Memórias do Instituto Oswaldo Cruz, Rio de Janeiro, v. 67, p. 1-886, 1969.

TRAVASSOS, L. Revisão da família Trichostrongylidae Leiper, 1912. Monografias do Instituto Oswaldo Cruz, Rio de Janeiro, 1937. v. 1, 807 p.

UENO, H.; GONÇALVES, P. C. Manual para diagnósticos das helmintoses de ruminantes. 4. ed. Tóquio: Japan International Cooperation Agency, 1998. $143 \mathrm{p}$.

VICENTE, J. J.; RODRIGUES, H. O.; GOMES, D. C.; PINTO, R. M. Nematóides do Brasil. Parte V: nematóides de mamíferos. Revista Brasileira de Zoologia, Curitiba, v. 14, p. 452, 1997. Suplemento 1.

YAMAGUTI, S. Systema helminthum. New York: Intercience Publ., 1961. v. 4, 423 p. 